\title{
Notes on Nematode parasites of Indian Mongoose, Herpestes mungo
}

\author{
(Etude de quelques Nématodes \\ parasites de la Mangouste indienne, $H$. mungo)
}

By Naunihal SINGH and B. P. PANDE

\section{Introduction}

The helminth parasites of mongoose have been studied, among others, by Vevers (1923), Ortlepp (1925), Hsü (1935), Webster (1956), Bronzini (1954), Gerichter (1948, 1951), Chabaud and Biocca (1950), Biocca and Chabaud (1952), Vuylsteke (1956), Yeh (1958), from countries abroad, while Mirza (1933), Mirza and Basir (1938), Rao (1939), Baylis (1939), Khera (1956) have dealt with some of the Indian representatives. The Indian records/reports, so far published, relate to Arthrocephalus gambiensis Ortlepp, 1925 ; A. herpestis Khera, 1956 ; a remarkable form considered intermediate between a nematode and an acanthocephalid and designated as Diserratosomus mungoosii Mirza, 1933 [believed to be a broken piece of Rictularia (Baylis, 1939)]; and another spiruroid - Spirura narayani Mirza and Basir (1938) and a filaroid species, Filaria martis Gmelin, 1790, reported by Vevers (1923).

\section{Material and Method}

Seven specimens of Herpestes mungo were autopsied by one of us (NS) during the teaching session, 1961-62, as a part of research project to investigate the parasitic fauna of wild, semi-domesticated, and domestic carnivores. The abdominal cavity revealed, amongst its viscera, specimens of thread-like nematode belonging to Pulmostrongylus Hsü, 1935 (= Herpestostrongylus Khera, 1956) amongst the fat surrounding the mesentery. The intestinal part of the alimentary tract yielded a large number of specimens of the hookworm, A. gambiensis, in addition to a trichurid. The stomach provided, amongst its contents, a few specimens of an oxyurid. The liver, prominently lesioned, after sectioning revealed an infection with a juvenile gnathostomid nematode. A specimen of $A$. gambiensis was once 
observed in the sediment from the incised pieces of liver. The lungs, heart and associated blood vessels were similarly searched for parasites and specimens belonging to two genera of lungworms - a metathelazid and a crenosomatid, were collected.

Wherever any organ/tissue exhibited lesions, such portions were fixed and subsequently sectioned serially. The stained preparations were examined to assess the host-parasite relationships and the attendant histopathological changes around the stages harboured. A brief account of the salient anatomical features of the various parasites with a few observations on the biology of some of these forms is attempted herein.

\section{Observations}

\section{ARTHROCEPHALUS GAMBIENSIS, Ortlepp, 1925.}

This hookworm, first collected from an African mongoose that had died in the gardens of Zoological Society of London, was made the genotype, under Ancylostomidae, of a new genus which was characterised chiefly by the absence of a buccal lancet and a completely articulated buccal capsule carrying a prominent dorsal cone.

Rao recovered specimens of the type species from the small intestine of common Indian mongoose, H. mungo, and appended a brief description. Two other species, A. maxillaris (Molin, 1860) and A. lotoris (Schwartz, 1925), Chandler, 1942 were assigned to this genus, the former has been stated to have been studied and redescribed from South American raccons by Vaz in 1938 and the latter, originally known as Uncinaria lotoris Schwartz, 1925, was studied from raccons in Texas by Chandler who removed it to Arthrocephalus. Thus, three species came to be known under this genus. A fourth, A. herpestis, from the small intestine of ruddy mongoose, A. smithii smithii, was added by Khera, in the publication dated 1954 but issued in 1956, who also gave a key for differentiating these four species. Webster (1956), after examining the hookworms from raccons, came to the conclusion that A. lotoris and A. maxillaris did not really belong to Arthrocephalus and accordingly recognised under it but one species, A. gambiensis. Khera's species, A. herpestis, could not be reviewed as both these papers were issued nearly simultaneously. Thus, we now have the two species, A. gambiensis and $A$. herpestis.

The specimens of hookworms, in the present collection, consist of 40 males and 50 females. The lining of the small intestine, harbouring the parasite, exhibited lesions of enteritis and the stained sections clearly depicted characteristic haemorrhagic spots, congestion of blood vessels and other important pathological changes including eosinophilic infiltration. A brief description of our own specimens, to bring out variations in the accounts given by Ortlepp, Rao and Khera, is given.

Worms small in size, thin in form, with anterior extremity characteristically bent dorsally, and mouth anterodorsally directed with six articulations surrounding the funnel-shaped buccal capsule with a well developed dorsal cone (fig. 1). Intestine full of blood, rectum with three conspicuous rectal glands of oval form lying near its beginning (fig. 2). 
Mâles : $5.63-5.98 \mathrm{~mm}$. in length and $0.16 \mathrm{~mm}$. in breadth. Buccal capsule $0.11 \times$ $0.05 \mathrm{~mm}$. in size. Esophagus $0.40-0.41 \mathrm{~mm}$. in length and $0.07-0.08 \mathrm{~mm}$. in breadth, clubshaped. Cervical papillae very small, at a distance of $0.40-0.41 \mathrm{~mm}$. from the anterior end.

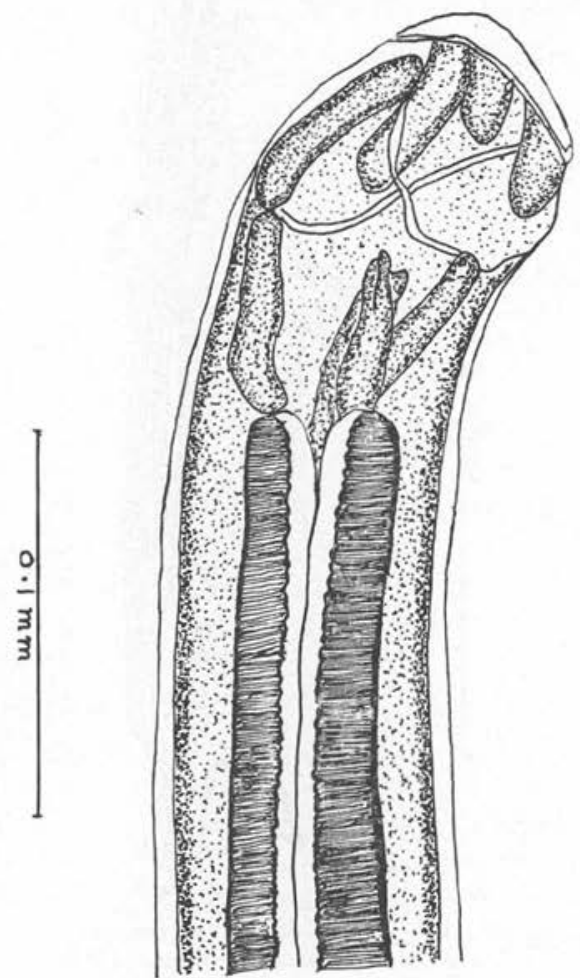

FIG. 1. - Extrémité antérieure montrant la courbure dorsale caractéristique

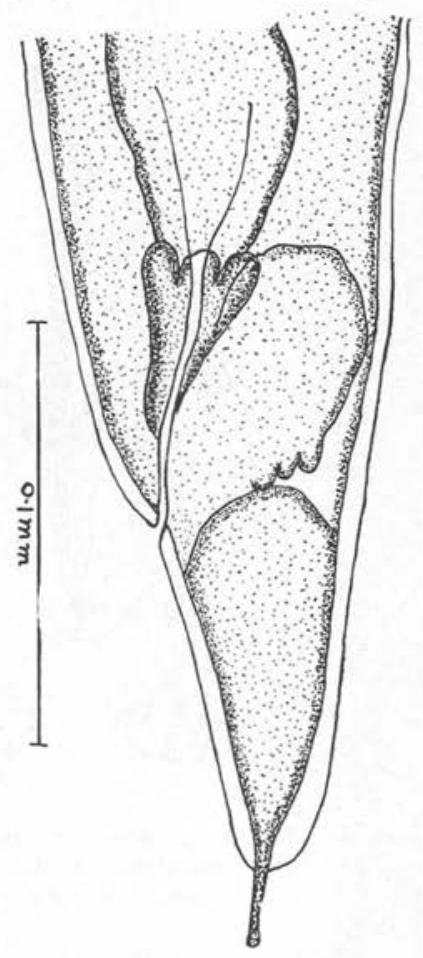

FIG. 2. - Extrémité postérieure de la femelle avec les glandes rectales

Bursa (fig. 3) well-developed, with two large lateral lobes and a small dorsal lobe. Ventral rays, for the greater part, united but separating only distally. Dorsal ray bifurcated distally with its branches ending in three digitations, the two inner ones parallel and the outer one (somewhat stouter but shorter) diverging laterally without exhibiting any L-shaped character (reported by Khera) (fig. 4). Lateral rays, with a common trunk, separating terminally. A prominent genital cone present near the junction of the dorsal and externodorsal rays (fig. 3). Spicules measuring $0.29 \mathrm{~mm}$., filamentous, knobbed proximally, with a slight curvature distally. Gubernaculum, situated near the origin of the externo-dorsals, somewhat tubular and $0.04 \mathrm{~mm}$. in length.

Females : $5.60-8.09 \mathrm{~mm}$. in length. Buccal capsule $0.102-0.104 \times 0.055-0.060 \mathrm{~mm}$ in size. Cervical papillae at a distance of $0.06 \mathrm{~mm}$. from anterior end. Vulva at $3.69-5.49 \mathrm{~mm}$. behind the anterior end, leading into a vagina of $0.05 \mathrm{~mm}$. in length. Common uterus 0.18$0.24 \mathrm{~mm}$. in length. Intra-uterine eggs $0.014-0.016 \mathrm{~mm}$. in size. Tail $0.13 \mathrm{~mm}$. long, followed by a spike of $0.014-0.016 \mathrm{~mm}$. in length. 
The specimen, recovered from the liver, was a developing female with a buccal capsule showing all its characteristics and of $0.10 \times 0.068 \mathrm{~mm}$. in size. In close

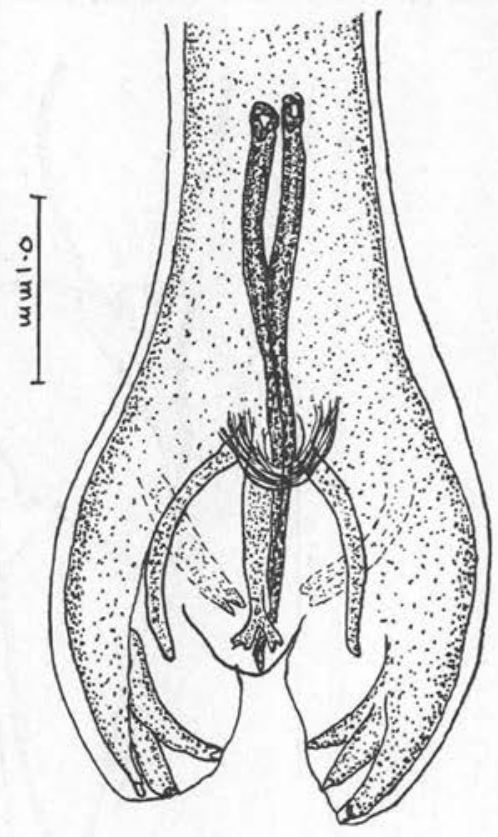

Fig. 3. - Bourse en position dorsale, montrant la disposition des côtes et le cône génital

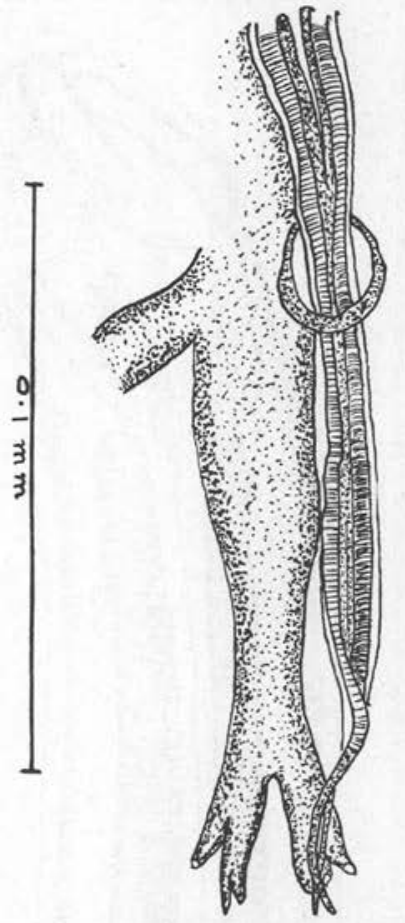

Fig. 4. - Côte dorsale et spicules avec le gubernaculum tubulaire

association with its oral opening, a plug of liver tissue was seen (fig. 5). Posteriorly, the characteristic rectal glands and the spike of $0.026 \mathrm{~mm}$. length (fig. 6) left no doubt about its identity.

Remarks. The present material does not exhibit any marked structural differences from either A. gambiensis, as described and illustrated by Ortlepp and Rao, or with $A$. herpestis which, according to Khera, is distinguished on account of the smaller size of the spicules and accessory piece as also the external of the three digits of the branches of the dorsal ray being L-shaped. The last distinguishing feature is not at all borne out in the diagram of its bursa. After our study of the material and a perusal of the relevant papers, we do not agree with Khera in his observations that the illustration given both by Ortlepp and Rao were unlabelled and not of much help in identification of various structures inside the buccal capsule. Apart from these, our specimens in the matter of measurements also come well within the range given by Ortlepp and Rao. A. herpestis is, therefore, suppressed as a synonym of A. gambiensis. 


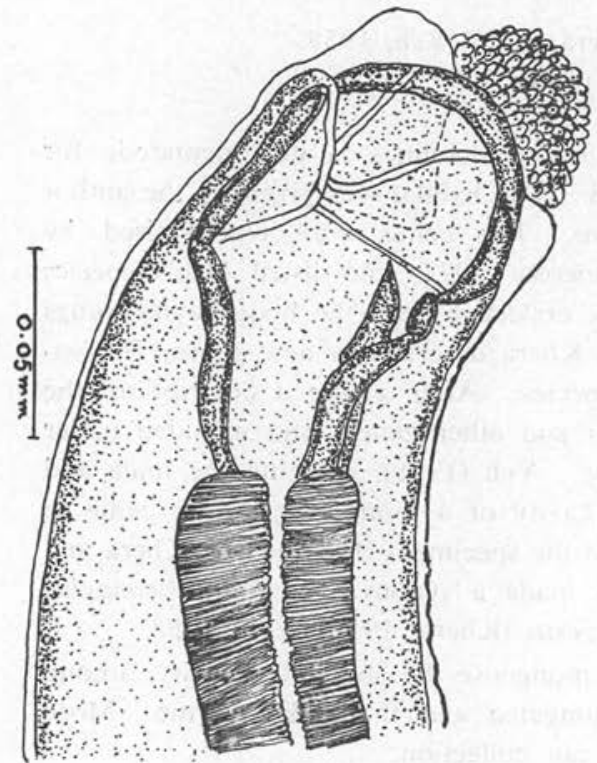

Fig. 7. - Extrémité antérieure montrant les papilles céphaliques, l'anneau nerveux et les papilles cervicales

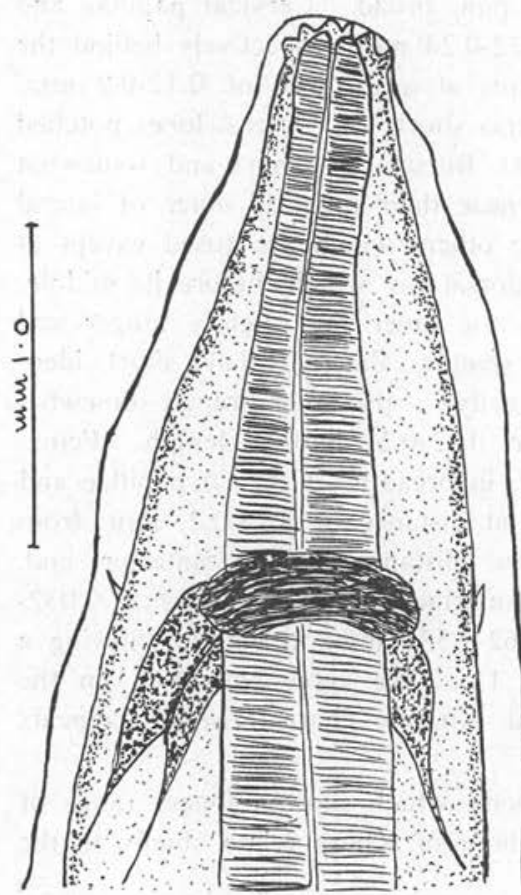

Fig. 5. - Extrémité antérieure d'une jeune femelle avec un fragment de tissu hépatique attaché à la capsule buccale

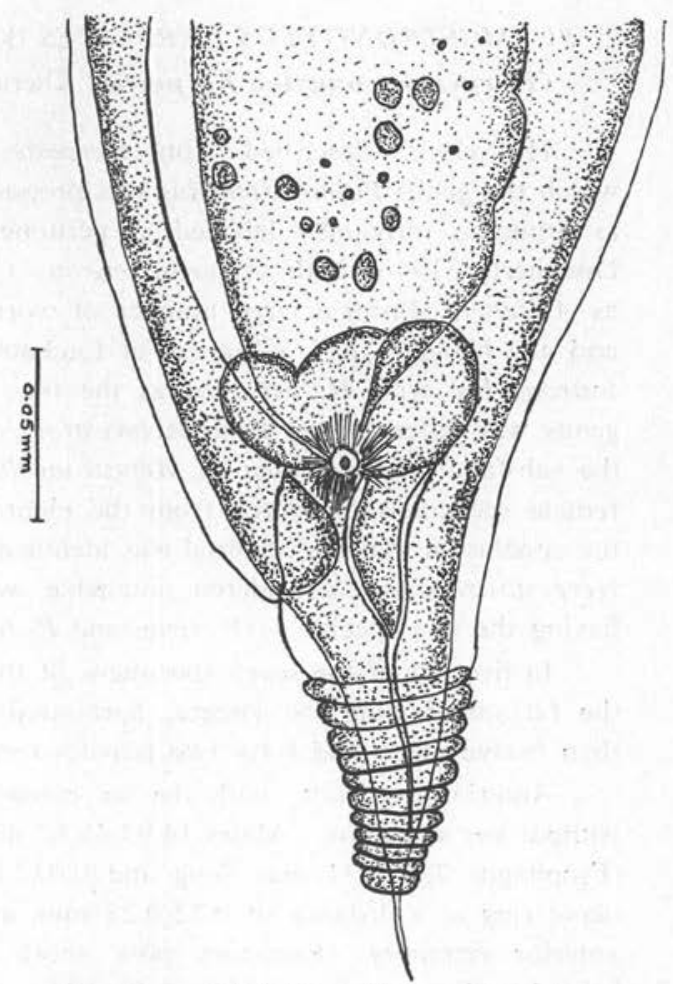

FIG. 6. - Extrémité postérieure de la forme hépatique montrant les glandes rectales caractéristiques

$P$. herpestis (fig. 7 à 11)

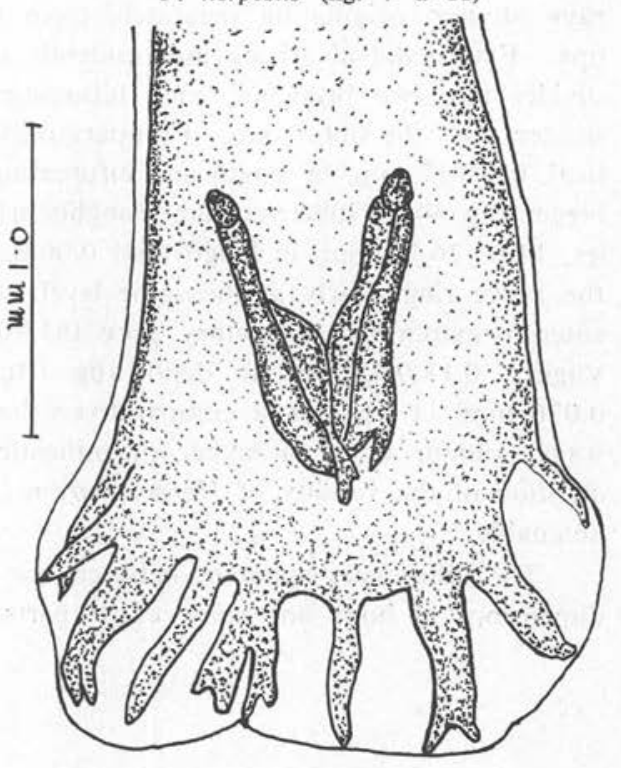

Fig. 8. - Bourse montrant les lobes, la disposition des côtes, les spicules et le 


\section{PULMOSTRONGYLUS HERPESTES (Khera, 1956) Yeh, 1958.}

\section{(Herpestostrongylus herpestis, Khera, 1956).}

Hsï (1935) described, from Herpestes urva (Indochina), a new nematode for which the genus Pulmostrongylus was proposed. The habitat was given by the author as bronchus (originally labelled as peritoneum). This genus was synonymised by Dougherty (1946) with Aelurostrongylus Cameron, 1927 who listed Hsü's species as $A$. fengi. From a large number of worms, collected from the body cavity, lungs and gall bladder of $\boldsymbol{H}$. edwardsii at Lucknow, Khera described a new genus, Herpestostrongylus, with $H$. herpestis as the type species. After giving a description, the genus was differentiated from Aelurostrongylus and other genera and included under the sub-family Filaroidinae of Metastrongylidae. Yeh (1958), studying the male and female specimens recovered from the pleural cavity of a mongoose in Fiji, came to the conclusion that the material was identical to the specimens described by Khera and Herpestostrongylus, considered untenable, was made a synonym of Pulmostrongylus having the two species - P. fengi and P. herpestis (Khera, 1956), Yeh, 1958.

In five out of the seven specimens of this mongoose the abdominal cavity, among the fat surrounding the viscera, harboured elongated and threadlike worms. More than twelve males and forty two females form our collection.

Anterior extremity with the six conspicuous papillae (fig. 7), blunt and cuticle without any striations. Males $14.93-18.67 \mathrm{~mm}$. in length and 0.03-0.2 mm., in breadth. Esophagus $0.28-0.31 \mathrm{~mm}$. long and $0.032-0.041 \mathrm{~mm}$. broad. Cervical papillae and nerve ring at a distance of $0.22-0.23 \mathrm{~mm}$. and $0.22-0.24 \mathrm{~mm}$. respectively behind the anterior extremity. Excretory pore more anterior, at a distance of $0.12-0.2 \mathrm{~mm}$. behind oral opening. Intestine full of blood. Bursa short, with lateral lobes notched in the middle - dorsal lobe being absent (fig. 8). Bursal rays short and somewhat stout. Ventral rays equal, parallel but separate near their middle; outer of lateral rays stouter, originating separately from the two others which are fused except at tips. Externodorsal arising independently of the dorsal ray which, before its middle, divides into two branches, each bifurcating with the inner one slightly longer and stouter than the outer one. Comparatively stout spicules alate, medially short, identical, 0.1-0.17 mm. in length and bifurcating terminally - the outer branch somewhat bigger (fig. 9). Gubernaculum roughly triangular, 0.32-0.52 mm. in length. Females, $14.80-26.72 \mathrm{~mm}$. in length and $0.06-0.37 \mathrm{~mm}$. in breadth. Cervical papillae and the nerve ring nearly at the same level, situated at distance of $0.16-0.2$. mm. from anterior extremity. Excretory pore $0.33-0.54 \mathrm{~mm}$. distance behind anterior end. Vagina $0.13-0.42 \mathrm{~mm}$. in depth (fig. 10). Intra-uterine eggs $0.054-0.062 \times 0.032$ $0.036 \mathrm{~mm}$. in size. Tail comparatively long, $0.162-0.531 \mathrm{~mm}$. in length, showing a wavy contour under a higher magnification (fig. 11). We agree with Yeh on the question of the validity of Herpestostrongylus and Khera's characterisation appears untenable.

The differences apparent between our specimens, which show a longer range of dimensions of body and some of its parts, and those of Khera relate chiefly to the 


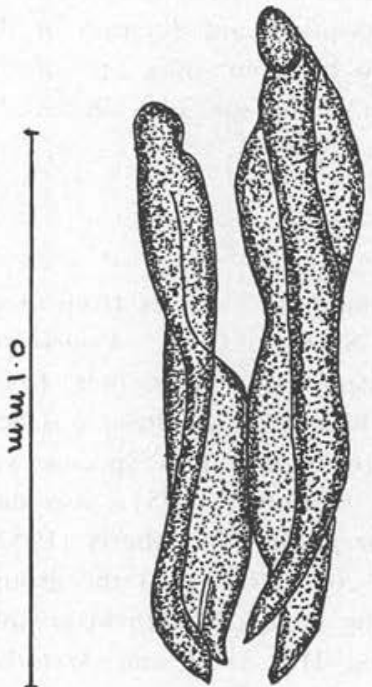

Fig. 9. - Spicules du mâle
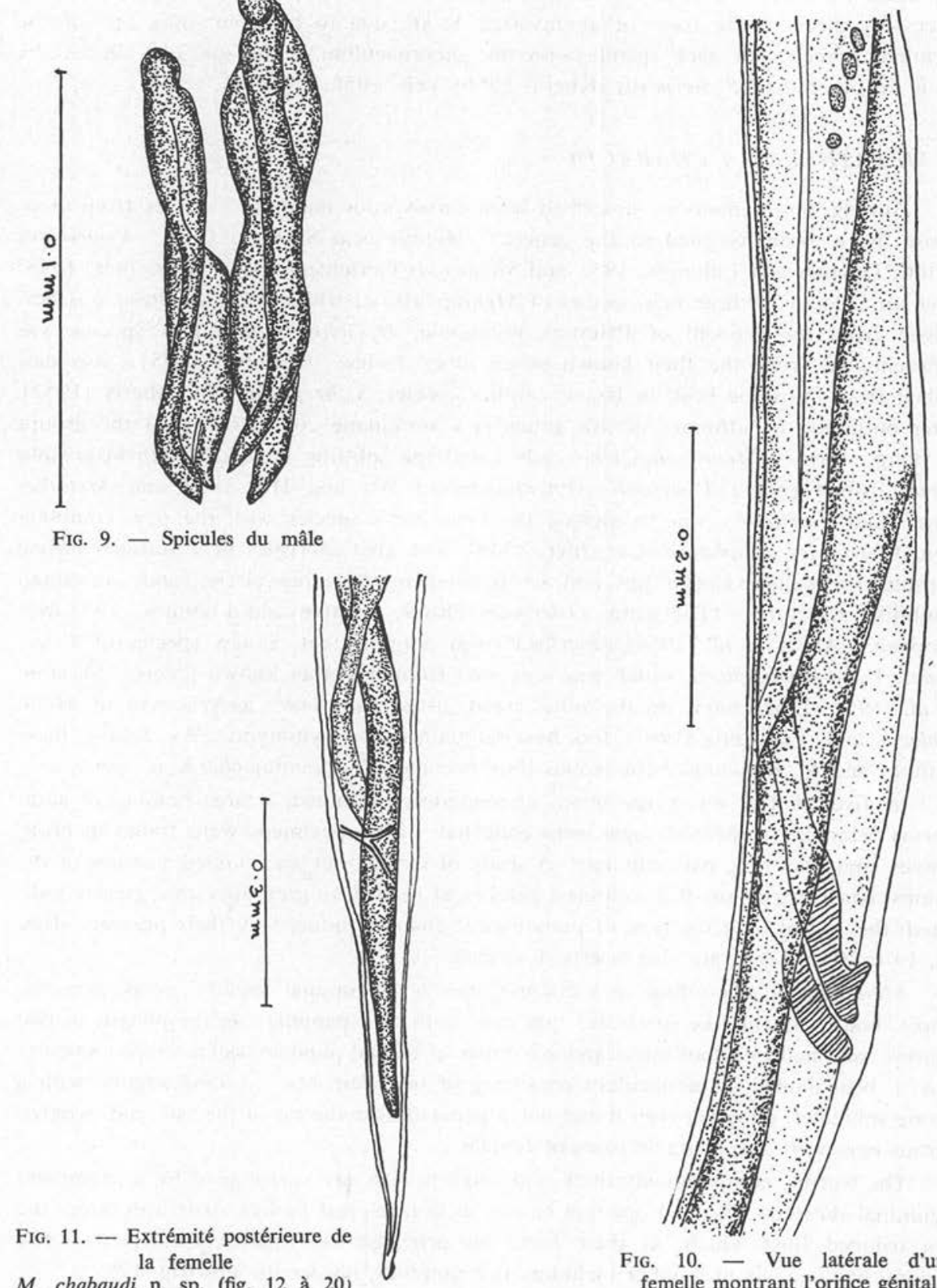

Fig. 10. - Vue latérale d'une femelle montrant l'orifice génital 
structure of spicules and gubernaculum and Khera's illustration does not seem to represent the structure of these parts correctly. His description and diagram of the accessory piece in the form of an inverted $\mathrm{Y}$ are due to his combining one of the terminal branches of each spicule with the gubernaculum. The species collected by us is no other than $P$. herpestis (Khera, 1956) Yeh, 1958.

\section{METATHELAZIA CHABAUDI, n. sp.}

Among lung nematodes, described from carnivorous mammals, species from mongoose have been assigned to the genera: Metathelazia Skinker, 1931; Vogeloides Orloff, Davtian and Lubinow, 1933 and Stenuroids Gerichter, 1951. Gerichter (1948) gave an account of three new species of Metathelazia of which $M$. aesophagea was described from the bronchi of Palestine mongoose, H. ichneumon. This species was differentiated from the then known seven other forms. Gerichter (1951) also described from the same host, in Israel, another species, S. herpestis. Dougherty (1952), after outlining the affinities of this genus in a systematic consideration of the groups of lung worms (Metastrongylidae), advocated the splitting up of Metathelazia into three distinct genera Vogeloides, Pneumospirura $\mathrm{Wu}$ and $\mathrm{Hu}, 1933$ and Metathelazia; and Vogeloides was to include the Gerichter's species with the new combination, Vogeloides asophagea (Gerichter, 1948), with characteristics of a vestigial buccal capsule, six well-developed lips and six papillae in the inner circle, and six small tooth-like structures. The genus Osleroides Orloff, Davtian and Lubinow, 1933 was dropped. Alwar et al. (1958) described from domestic cat a new species of Vogeloides, $V$. ramanujacharii, which was separated from the other known forms. Skrjabin et al. $(1952,1961)$ have, on the other hand, listed Vogeloides as synonym of Metathelazia and Yamaguti (1961) too has maintained the synonymy. We follow these authors and $V$. ramanujacharii would thus become $M$. ramanujacharii. n. comb.

In five of the seven specimens of mongoose examined, a large number of adult worms belonging to Metathelazia were collected. The specimens were found in bronchioles and the lung parenchyma. A study of serially cut and stained sections of the lesions, consisting of small discoloured patches of reddish to grey in colour, clearly indicated the extent and the type of pathological changes induced by their presence (figs. $18,19 \& 20$ ). These are also briefly described.

Metathelazia, according to Gerichter, has a 'teguminal sheath' enveloping the whole body ; six lip-like structures ; six oral teeth ; six papillae ; an cesophagus in two regions ; and male without bursa and a number of caudal papillae, sickle-shaped spicules and a boat-shaped gubernaculum consisting of two elements. A long vagina, with a strong sphincter, lying between it and vulva situated near the tip of the tail, and ovoviviparous eggs were the characteristics of female.

The worms, comparatively thick and small in size, are surrounded by a prominent teguminal sheath. The oral opening has six well-developed lip-like structures (from the two trilobed lips) which, at their base, are provided with small conical teeth. The perioral papillae, six in number including two amphids, border the lips (fig. 12). 

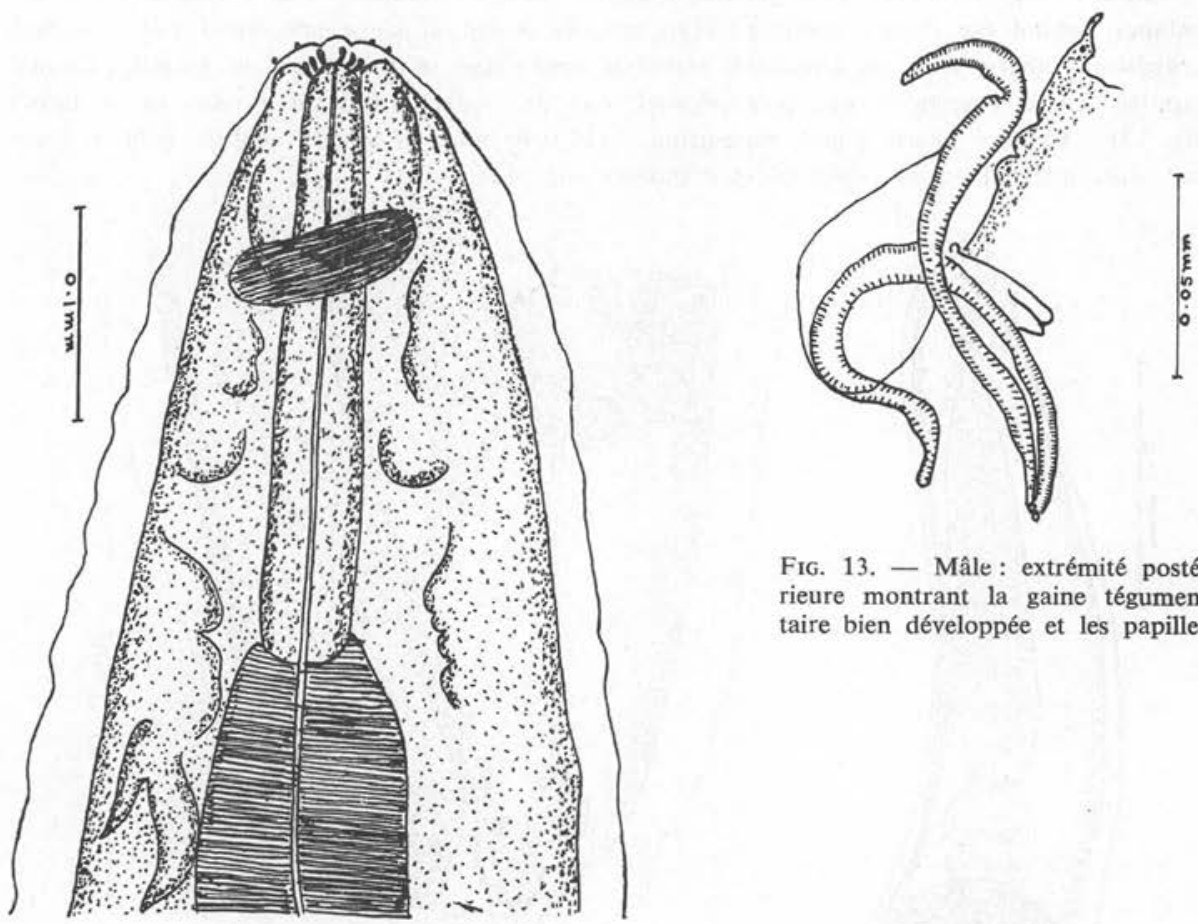

Fig. 13. - Mâle: extrémité postérieure montrant la gaine tégumentaire bien développée et les papilles

Fig. 12. - Extrémité antérieure montrant les papilles céphaliques et les dents

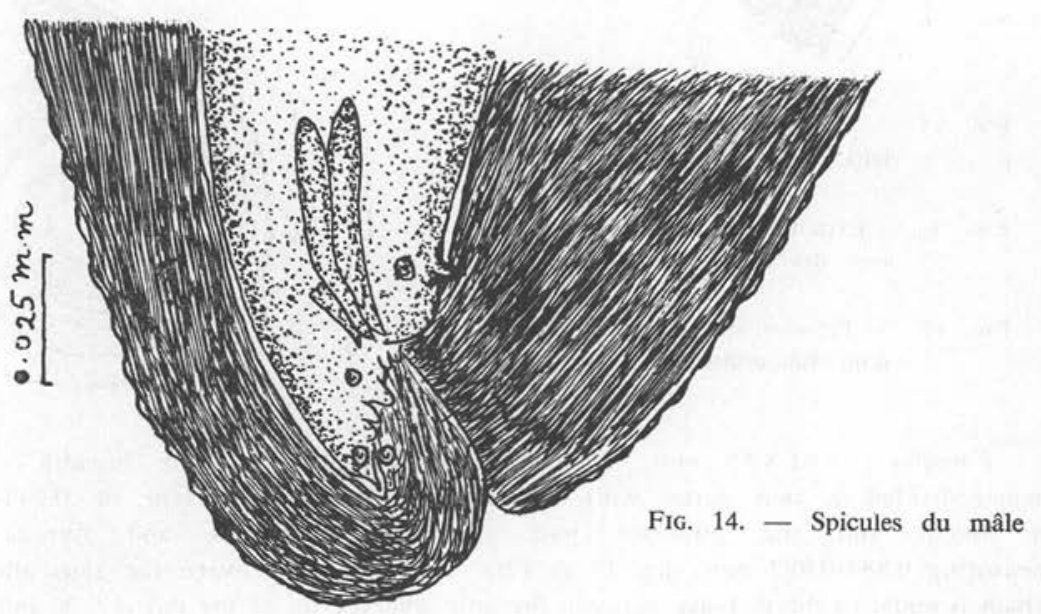


Mâles : $4.21-5.46 \mathrm{~mm}$. in length and $0.22-0.27 \mathrm{~mm}$. in breadth. Nerve ring at $0.09 \mathrm{~mm}$. distance behind the mouth opening. Tail spirally coiled in some specimens but relatively straight in others, with an elongated terminal appendage of $0.06 \mathrm{~mm}$. in length. Caudal papillae ten, consisting of one pair preanal, one pair adanal and three pairs of postanals (fig. 13). Spicules nearly equal, measuring $0.112-0.40 \mathrm{~mm}$. in length, slightly bent in form and with internal edges comparatively thinner (fig. 14).
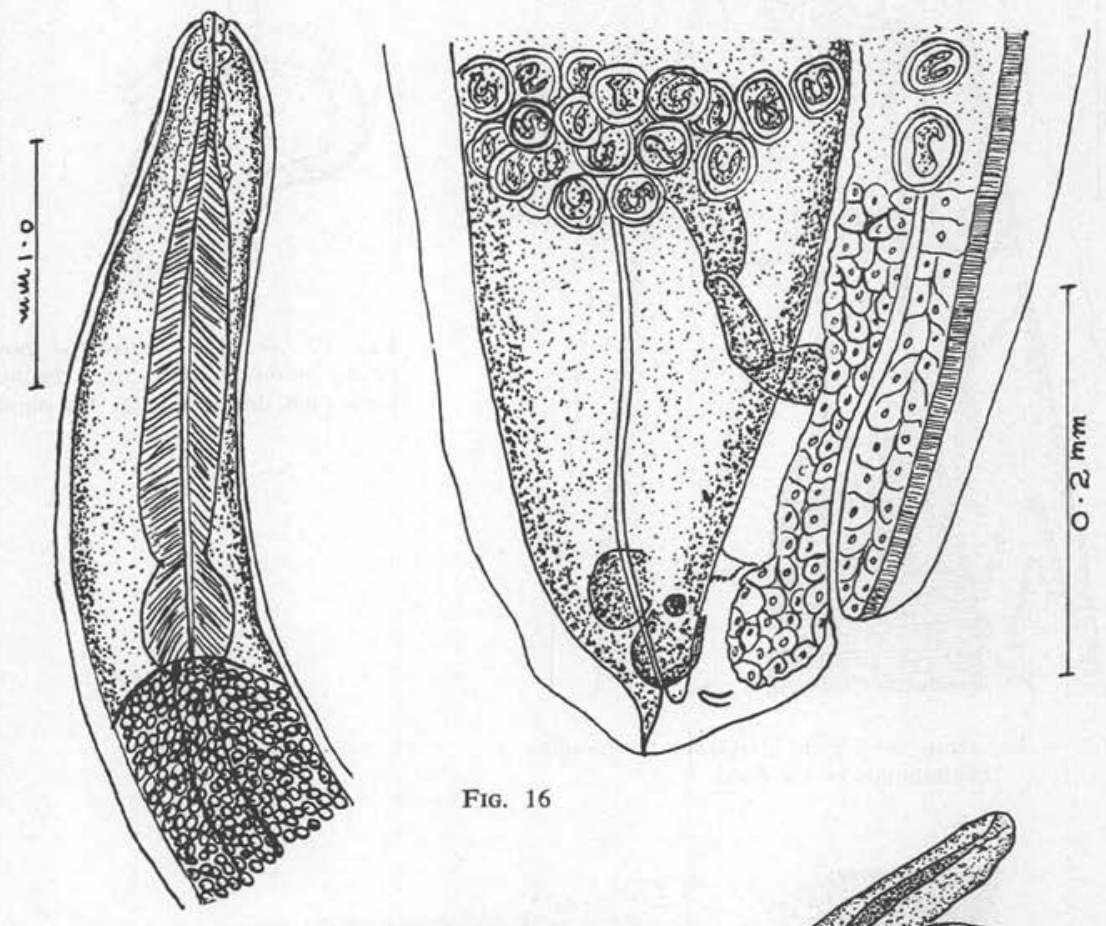

Fig. 16

Fig. 15. - Extrémité antérieure montrant deux parties de l'œsophage

FIG. 16. - Extrémité postérieure de la femelle avec des œufs embryonnés

FIG. 17. - Premier stade larvaire provenant d'un échantillon de selles

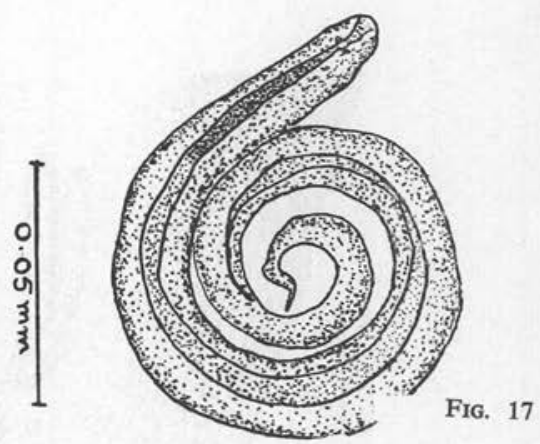

Females : 6.61-8.65 mm. in length and 0.41-0.44 mm. in breadth. Esophagus clearly divided in two parts, with the anterior glandular portion of $0.241-0.288 \mathrm{~mm}$. in length and the posterior part (with its glandular and fibrous elements) measuring $0.881-0.982 \mathrm{~mm}$. (fig. 15 et 12). The distance between the anus and the vulva which is equal to the distance between the anus and the tip of the tail is $0.06 \mathrm{~mm}$. A pro- 
minent sphincter is present around the vulvar opening (fig. 16). Vagina 0.12-0.16 mm. long, proximally continuing into the two uteri. Intra vaginal eggs fully embryonated, thickshelled, measuring $0.040 \times 0.028 \mathrm{~mm}$. in size. A few first stage larvae, that had hatched in the faecal mass, measured $0.3 \mathrm{~mm}$. in length with the tip of the tail carrying two notches the dorsal one shallower than the ventral which give to it an undulatory character (fig. 17). This feature of the posterior end was also noticed in the sections of larvae. According to the useful key given by Gerichter the present material, on account of the presence of six conspicuous perioral lip-like structures, resembles the species: $M$. asophaga Gerichter, 1948 ; M. hainanensis (Wu and Hu, 1938) Dougherty, 1943 ; M. massinoi (Davtian, 1933), Dougherty, 1943 and M. ascaroides (von Linstow, 1879), Dougherty, 1943.

In $M$. hainanensis, $M$. massinoi and $M$. ascaroides, the œsophagus has been stated to be less than $1 / 10$ th of the entire body length. The present form, however, shows some affinities to $M$. asophagea which has the csophagus of more than $1 / 7$ th of the total body length and the distance of the vulva to the anus is equal to the distance between anus and of the tail. M. chabaudi, n. sp., appears quite distinct because male papillae in the Palestine form, $M$. asophagea, are in 9 pairs and the spicules 0.21 $-0.23 \mathrm{~mm}$. long. The present material also differs from $M$. ramanujacharii (Alwar et al.) in the number of the caudal papillae which have been described as indistinct and consisting of two pairs of preanal and two pairs of postanal papillae only. Further, in this species the proximal ends of the spicules have been described as thickened with a knob-like hooked process but are blunt distally. The body dimensions in our material are almost half of those described for $M$. ramanujacharii. In $M$. exilis (Biocca and Chabaud, 1952) from a mongoose, $H$. caffer, the caudal papillae, according to Alwar et al., consist of four pairs of preanal, one pair of adanal and one pair of postanal. On the basis of these differences, the present form is tentatively assigned to a new species designated as Metathelazia chabaudi, in honour of Prof. Alain G. Chabaud.

\section{Histopathology.}

The reactions around the parasite, mainly of a sub-acute character, consist of heavy lymphocytic infiltration which was also observed in the collapsed air spaces (fig. 18). The adjacent areas in the lung parenchyma reveal congestion and areas of haemorrhage. A compensatory emphysema is also present in the alveoli. Eosinophils were entirely absent (fig. 19 \& 20).

(The type specimens deposited in the collection of the Department.).

\section{A CRENOSOMATID INFESTATION.}

The lung worm infestation with metastrongylids in carnivores is associated with a number of genera such as ; Aelurostrongylus Cameron, 1927 ; Bronchostrongylus Cameron, 1931 (Syn Haemostrongylus Railliet and Henry, 1907 partim); Pulmostrongylus Hsü, 1935 ; Troglostrongylus Vevers, 1922 ; Angiostrongylus Kamensky, 1905 (= Haemostrongylus Railliet, 1865); Crenesoma Molin, 1861 and Stenuroides Gerichter, 1951. 

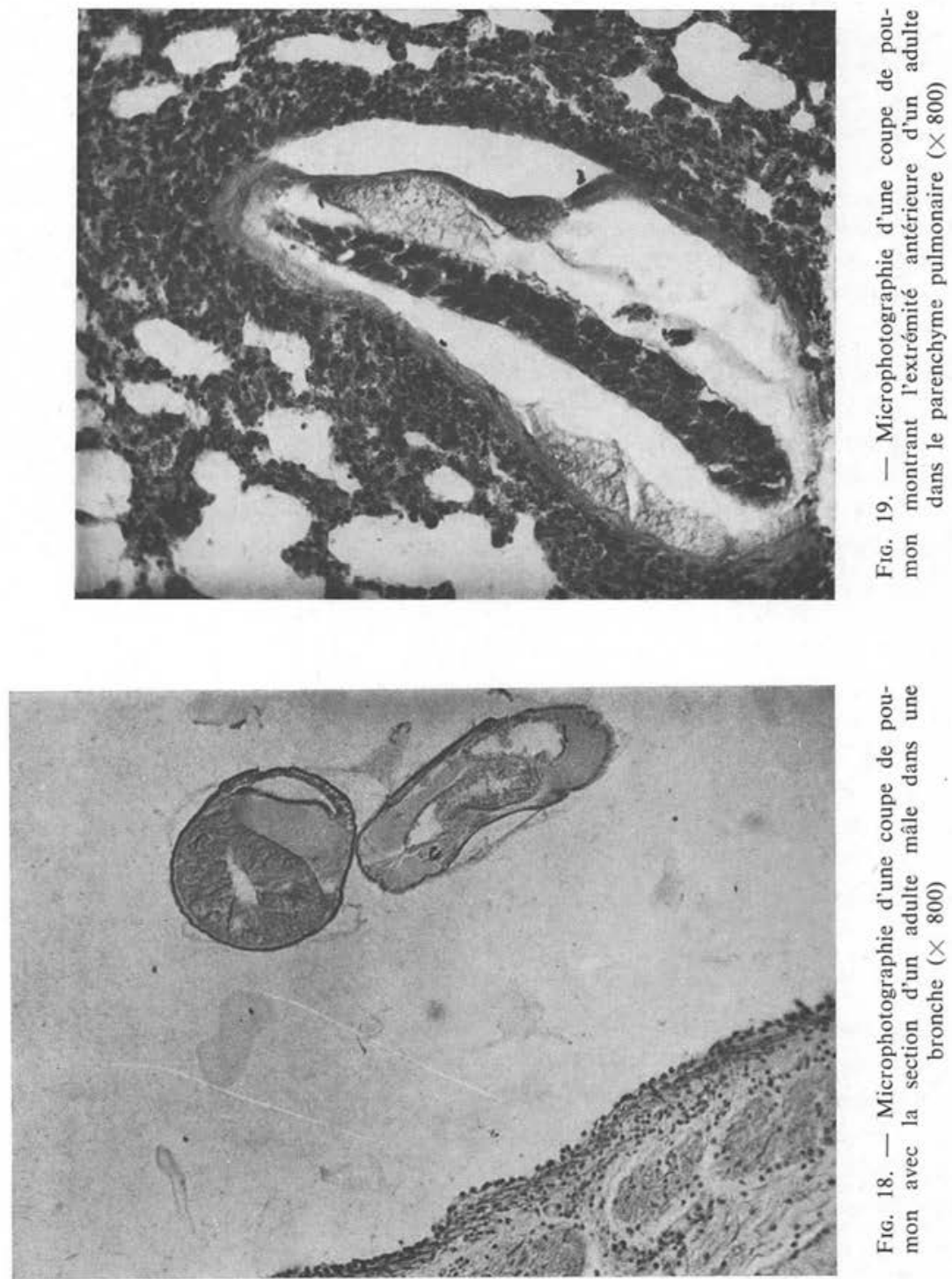

As far as it could be ascertained, mongoose is known to be a host for Pulmostrongylus fengi Hsü, 1935 [= Aelurostrongylus fengi (Hsü, 1935) Dougherty, 1946].

Of the four incomplete specimens of a bursate worm, encountered in the present collection, two were with complete bursa and in two others the anterior end alone was intact. The anterior part of the body, with a tapering extremity, is transversely striated 
- the striations separated by a distance of $0.016 \mathrm{~mm}$ (fig. 21). The small buccal capsule carries six lips around the mouth. The œsophagus measures $0.41 \mathrm{~mm}$. in length and $0.028 \mathrm{~mm}$. in breadth. The bursa and its pattern of rays, the structure of the spicules and the features of its anterior extremity could alone assist in identification of the specimens. Complete measurements for males and a description of the females are not possible. Accordingly, a correct determination of its specific identity was difficult. The distinctly developed bursa with its lateral lobes and a large dorsal lobe which, near its middle, is deeply notched (fig. 22). Dorsal ray with a median stout trunk and two terminal branches has an appearance of an inverted Y. Short externodorsals arise independently of the dorsal ray. Of the three laterals, the antero-lateral diverges from the two other laterals which, except at their tips, are nearly fused. Ventral rays also completely fused but for their tips. Spicules equal, $0.12 \mathrm{~mm}$. in length, with alae broad and transversely striated. Gubernaculum of the shape of an inverted Y. (fig. 23).

According to Yorke and Maplestone (1926), a gubernaculum is absent in Haemostrongylus but present in Crenosoma. Baylis (1929) stated that Aelurostrongylus has a small accessory piece while Angiostrongylus is without it. Hyman (1951) similarly mentioned that the crenulated annules, on the anterior part of the body, were a characteristic feature of Crenosoma, which was reviewed by Dougherty (1946) who also studied Aelurostrongylus and Angiostrongylus, the latter, except for A. gubernaculatus Dougherty (1946), is without gubernaculum.

The present material, after a study of its bursal pattern and arrangment of its rays, characters of its spicules, the gubernaculum and the annulations on the anterior part, cannot be properly assigned to any of the species of Crenosoma or Angiostrongylus.

A correct identification of this material has to await the discovery of females and availability of complete male specimens.

5. TRICHURIS TRICHIURA (Linnaeus, 1771), Stiles, 1901.

On two occasions, whip-worm infestation was encountered in the caecum of the mongoose autopsied. Both female and male worms were collected. The females, complete in all aspects, measure $21.8-36.34 \mathrm{~mm}$. in the œsophageal region and 12.01$16.23 \mathrm{~mm}$. in the wider intestinal part which has a breadth of $0.427-0.792 \mathrm{~mm}$. The eggs-barrel-shaped in form and with transparent polar plugs, are $0.068 \times 0.028 \mathrm{~mm}$. in size. All the three male specimens, in our collection, had the anterior region damaged and the wider region, measuring $12.8 \mathrm{~mm}$., was only available. The single lanceolate spicule is $2.184-3.23 \mathrm{~mm}$. in length and its retractile sheath carried numerous recurved spines.

The specimens belong to Trichuris trichiura (the human whipworm) which is associated with human trichuriasis in most of the tropical countries. It has also been reported from pig and some monkeys. Its incidence in mongoose, a first record, enlarges the list of its reservoirs amongst animals. 


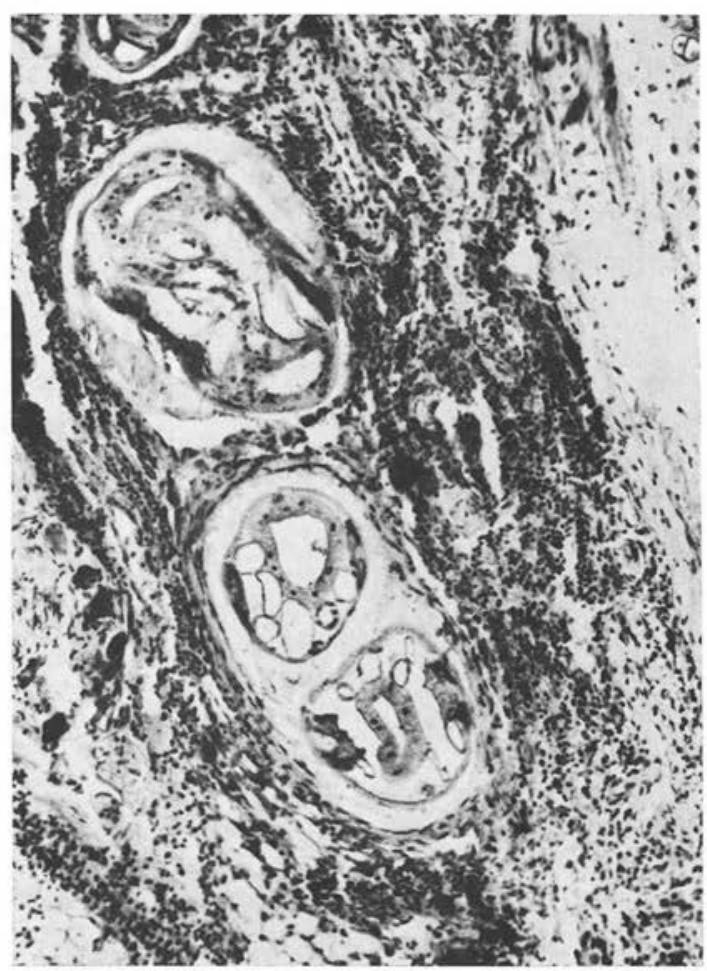

FIg. 20. - Microphotographie d'une autre section de ver adulte, montrant une réaction inflammatoire typique $(\times 800)$

Crenosoma (fig. 21 à 23)

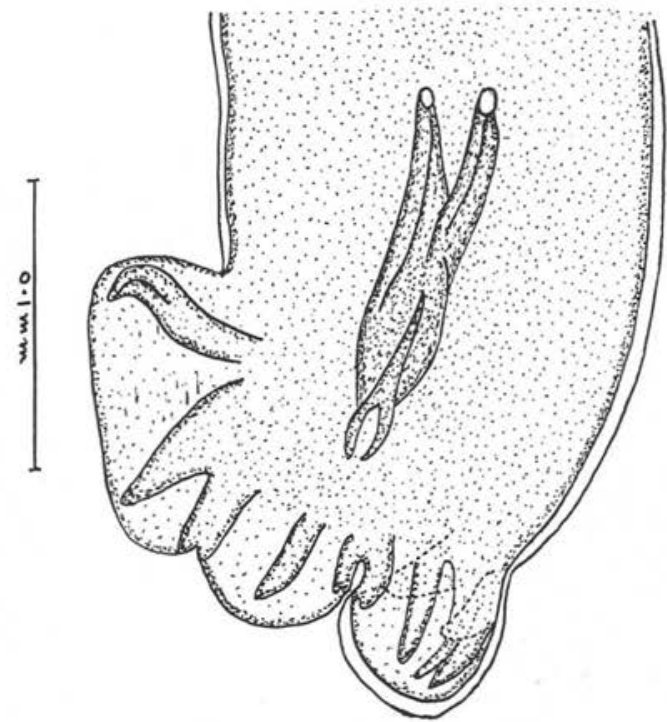

F1G. 22. - Bourse avec le lobe dorsal profondément encoché et les côtes caractéristiques

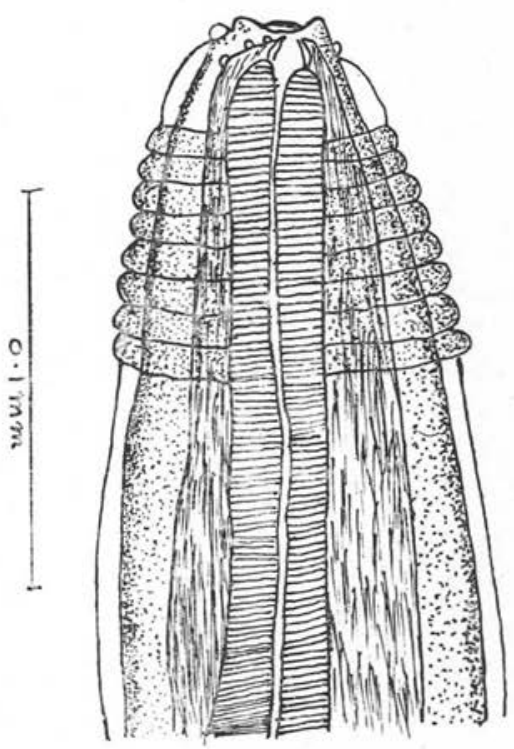

FIG. 21. - Extrémité antérieure montrant anneaux et lèvres

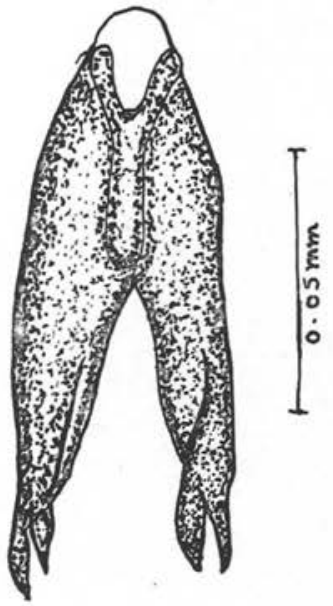

Fig. 23. - Spicules du mâle Gnathostomide jeune (fig. 24 à 26) 


\section{OXYURID INFESTATION.}

Infestation with oxyurid is known from all categories of vertebrates and these parasites, in general, inhabit the large intestine. Some genera have also been reported from invertebrates and a considerable literature is available on these forms.

The present collection consists of nine worms, all females, collected from stomach on two occasions, some being immature while others contained fully embryonated eggs and a solitary case was of an ensheathed form. These specimens are difficult to identify on account of the absence of males and their unusual habitat.

Thapar (1925) recorded, from the stomach of Testudo tabulata, Atractis dotyluris Rud., 1819 which is entirely different as its œsophagus is provided with two bulbs and the body dimensions are nearly double to those in our specimens. Another reptilian species, Tachygonetria vivipara Weld., 1862 (=Tachygonetria jugurthae Seurat, 1918), has been described by Thapar from the caecum of Uromastix acanthinurus and Iguana tuberculata. This oxyurid shows a striking resemblance to the present material in its general topography and the dimensions of body parts which, for our specimens, are : Body length 2.73-4.29 mm. ; Breadth 0.312-0.436 mm. ; Length of œsophagus, 0.39$0.436 \mathrm{~mm}$. Breadth of œsophagus $0.093-0.101 \mathrm{~mm}$. ; size of bulb $0.09 \times 0.06 \mathrm{~mm}$. ; Distance of excretory pore from anterior end $0.904 \mathrm{~mm}$. ; Distance of the vulva from anterior end 1.21-1.613 mm. ; Length of tail $0.36-0.480 \mathrm{~mm}$.

Probably, the specimens of mongoose, yielding the present material, had ingested the normal host of the pin-worm encountered in its stomach and the action of the gastric juices released the parasite in the gastric lumen.

\section{GNATHOSTOMID INFESTATION OF LIVER.}

The stained sections of the prominent white hapatic lesions exhibited a juvenile stage of a nematode with following characters : the anterior region of the body revealing an armature of recurved prominent scale-like spines arranged alround, the œsophagus with a characteristic musculature and lumen, and body cavity having cervical sacs and membranous cavities (fig. 24) which clearly suggested a gnathostomid affinity. The infection was, therefore, from a juvenile representative of one of the genera of Gnathostomidae Railliet, 1891, in which the presence of four cavities, communicating with cervical sacs, lying free in the body cavity, are the chief caracteristics. On account of nonavailability of adult form, its generic and specific diagnosis was not possible.

The attendant pathological changes noticed in the available sections consisted mainly of a mechanical destruction of the parenchymatous tissue which revealed congestion of blood vessels and extensive haemorrhage. No cellular changes were, however, apparent (fig. $25 \& 26$ ). Occurrence of larval gnasthostomids have, from liver, been reported by some workers. Ash (1962), in studies on migration and development of Gnathostoma procyonis Chandler, 1942, in mammalian hosts, found larvae only infrequently but has referred to the findings of larvae of G. spinigerum in liver of cats by Chandler (1925), larval migration in living dogs as obligatory phase of development 


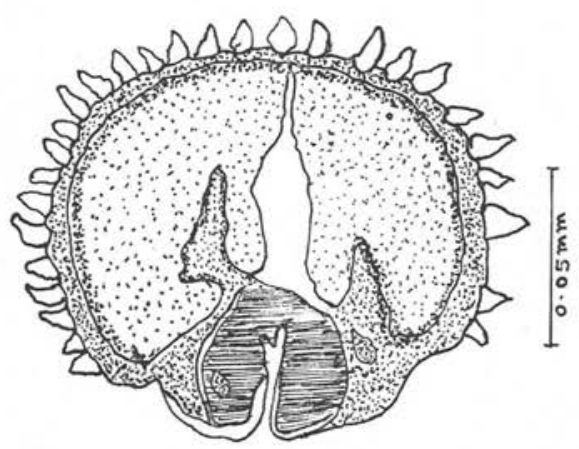

FIG. 24. - Dessin à la chambre claire, montrant l'armature caractéristique du corps et la structure interne (extrémité antérieure)

Fig. 26. - Autre coupe montrant la section d'une larve et la réaction congestive des vaisseaux voisins

FIG. 25. - Coupe d'une larve montrant les altérations pathologiques périphériques (dessin à la chambre claire)
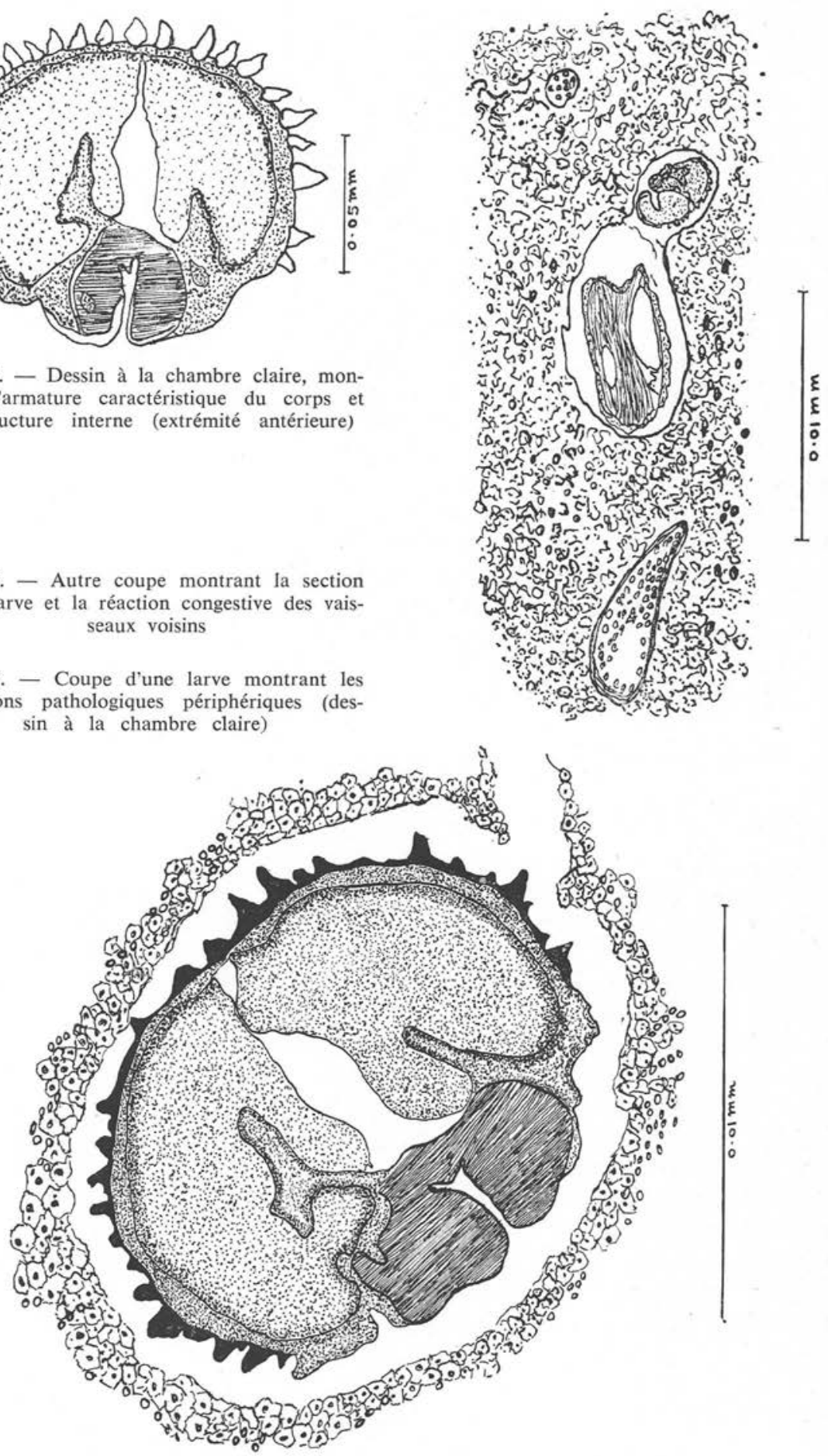
reported by Isobe (1952) and also in such abnormal hosts as rats recorded by Sagara (1953). In the case of $G$. hispidium, the liver migration reported by Buljevic (1960) has also been mentioned by Ash who also refers to the recovery of immature specimens of $G$. didelphis in the liver of opossums by Chandler (1932).

\section{Acknowledgment}

Thanks are due to the Principal of the college for the facilities provided.

\section{Summary}

The seven different types of nematode parasites from seven specimens of Indian mongoose, Herpestes mungo, include forms collected from the small intestine, abdominal cavity, lungs, stomach and liver. These have briefly been described along with observations on the lesions encountered. The two hookworms, Arthrocephalus gambiensis and $A$. herpestis, previously reported, have been found to be identical and the latter has been suppressed as a synonym of the former. The metastrongylid from abdominal cavity, Pulmostrongylus herpestis (Khera, 1956) Yeh, 1958, has briefly been described and the inaccuracies in Khera's account pointed out. The metathelazid infestation of the lung has been identified as due to a new species of Metathelazia, $M$. chabaudi, n. sp., which has been differentiated from the other known forms. A brief account of its histopathology has also been attempted. A few specimens of a crenosomatid form, collected from lung, has been reported. Besides Trichuris trichiura in the caecum, an oxyurid was met with in the stomach, and the liver, exhibiting prominent lesions, revealed a juvenile stage of a gnathostome. The reactions noticed in the liver tissue have been indicated.

\section{Résumé}

Sept espèces différentes de Nématodes, parasites de sept spécimens de la mangouste indienne, Herpestes mungo, ont été isolées. Elles comportent des formes rencontrées dans l'intestin grêle, la cavité abdominale, les poumons, l'estomac et le foie.

Les auteurs en fournissent une rapide description avec des observations sur les lésions observées.

Les deux espèces d'Ancylostomidae: Arthrocephalus gambiensis, et A. herpestis, décrites antérieurement, se sont avérées identiques et cette dernière espèce a été mise en synonymie avec $A$. gambiensis.

Le Métastrongylide Pulmostrongylus herpestis (Khera, 1956) Yeh, 1958, est brièvement décrit et les inexactitudes de la description de Khera sont signalées.

L'infestation à Métathélazides du poumon est identifiée. Elle est imputable à une espèce nouvelle de Metathelazia, M. Chabaudi n. sp., nettement différenciée des autres formes connues.

Les réactions histopathologiques sont rapportées. Quelques spécimens d'une forme de Cronosomatidae découverts dans le poumon sont étudiés. 
A côté de Trichuris trichiura de caecum, 9 femelles d'Oxyurides ont été trouvées dans l'estomac, tandis que le foie, qui présentait d'importantes lésions, révélait la présence d'un stade jeune de Gnathostome.

Les réactions observées au niveau du tissu hépatique sont indiquées.

\section{Références bibliographiques}

Alwar (V. S.), Lalitha (C. M.) and Seneviratna (P.), 1958. - Vogeloides ramanujacharit n. sp., a new lung worm from the domestic cat (Felis catus L.) in India. Indian Vet. J. 35 (1), 1-5.

AsH (L. R.), 1962. - Migration and development of Gnathostoma procyonis Chandler, 1942, in Ist and 2nd intermediate hosts. J. Parasitol., 48, 306-313.

BAYLis (H. A.), 1929. - A manual of Helminthology. Bailliere, Tindall and Cox. London, $303 \mathrm{pp}$.

-, 1939. - Nematoda V. 2. (Filarioidea, Dioctophymoidea and Trichinelloidea) (The Fauna of British India including Ceylon and Burma), 274 pp.

Biocca (E.) and Chabaud (A.-G.), 1952. - Description d'une nouvelle espèce du genre Metathelazia (Nematoda, Spiruroidea). Ann. Parasitol., 27 (4), 394-399. (Helminth. Abstr. 21).

Bronzini (E.), 1954. - Il Centro di parasitologia del Giardino Zoologico di Roma. (Elenco delle nurve specie di parassiti descritte). Nuovi. Ann. Ig. e Microbiol., 5 (1), 53-64. Helminth. Abstr. 23).

Chabaud (A.-G.) and Biocca (E.), 1950. - Description de Metathelazia servalis, n. sp., et observation sur le genre Metathelazia. Bull. Soc. Zool. France, 75 (5/6), 260-267. (Helminth. Abstr., 19).

Dougherty (E. C.), 1943. - The phylogeny of the nematode family Metastrongylidae Leiper (1909); A correction of the host and symbiotoc evolution. Parasitology, 39 (3/4), 222-234.

-, 1946. - The genus Aelurostrongylus Cameron, 1927. (Nematoda: Metastrongylidae), and its relatives; with descriptions of Parefilaroides gen. nov. and Angiostrongylus gubernaculatus sp. nov. Proc. Helm. Soc. Wash., 13 (1), 16-25.

-, 1952. - A note on the Genus Metathelazia Skinker, 1931 (Nematoda: Metastrongylidae). Proc. Helm. Soc. Wash., 19 (1), 55-63.

Gerichter (C. B.), 1948. - Three new species of the genus Metathelazia (Nematoda). J. Parasitol., 34 (2), 75-83.

—, 1951. - Two new lung Nematodes from Near-east Mammals. Parasitology., 41 (3-4), 184-188.

Hsü (H. F.), 1935. - A study of some Strongyloidea and Spiruroidea from French Indo-China and of Thelazia chungkingensis Hsü, 1933 from China. Zeitschr. Parasit., 7 (5), 579-600. (Helminth. Abstr., 4).

Hyman (H. L.), 1951. - The Invertebrates: Acanthocephala, Aschelminthes, and Entoprocta; the Pseudocoelomate Bilateria. Vol. III New York: Mc Graw-Hill Book Company, Inc., 572 pp. 
KHERA (S.), 1956. - Nematode parasites of some Indian Vertebrates. Indian J. Helm., 6 (2), 27-133.

MIRZA (M. B.), 1933. - On a new nemathelminth from Herpestes mungo. Zeitschr. Parasit., 6 (1), 145-146 (Helminth. Abstr., 2).

MIRZA (M. B.) and BASIR (M. A.), 1938. - On a collection of nematodes from Hyderabad Deccan (India) Zeitschr. Parasit., Berlin, 10 (2), 217-220 (Helminth. Abstr., 7).

ORTLePP (R. J.), 1925. - On Arthocephalus gambiensis, n. g., n. sp., a new Ankylostome from an African mongoose. J. Helminth., 3 (3-4), 151-156.

Rao (M. A. N.), 1939. - Arthrocephalus gambiensis Ortlepp, 1925. Indian J. Vet. Sc. and Animal Husb., 9 (1), 37-38.

Thapar (G. S.), 1925. - Studies on the Oxyurid parasites of Reptiles. J. Helm., 3 (3/4), 83-150.

Skrjabin (K. I.), Shikhobalova (N. P.) Schulz (R. S.), Popoba (T. I.), Boev (S. N.) et Delyamure (S. L.), 1952. - [Descriptive catalogue of parasitic Nematodes. Vol. 3. Strongylata] (In Russian). Izdat. Akad. Nauk, S.S.S.R., 890 pp.

—, 1961. - Key to Parasitic Nematodes. Vol. III. Strongylate. Israël. Program for Scientific Translations, $890 \mathrm{pp}$.

Vevers (G. M.), 1923. - On the parasitic Nematoda collected from Mammalian hosts which died in the Gardens of the Zoological Society of London during the years 19191921 ; with a description of three new genera and three new species. Proc. Zool. Soc. London. (3), 901-909.

VUYLSTEKe (C.), 1956. - Note sur quelques nematodes parasites avec description de neuf espèces nouvelles. Rev. Zool. et. Bot. African., 53 (3/4), $441-477$ (Helminth. Abstr. 30).

Webster (G. A.), 1956. - Placoconus: a new genus for Arthrocephalus lotoris (Schwartz, 1925), Chandler, 1942. Canad. J. Zool., 34 (2), 99-103.

Yamaguti (S.), 1961. - Systema Helminthum. Vol. III. The Nematodes of Vertebrates. Part I and II, 1261 pp.

YeH (L. S.), 1958. - A redescription of Pulmostrongylus herpestis (S. Khera, 1956), n. comb. from the lung of mongoose, Herpestes sp. from Suva, Fiji, J. Helminth., 32 (1/2), 93-98.

Yorke (W.) and MAPelstone (P. A.), 1926. - The Nematode parasite of Vertebrates. J. and A. Churchill, London, $536 \mathrm{pp}$.

[Department of Parasitology, U.P. College of Veterinary

Science and Animal Husbandry, Mathura (U.P.) India] 